\title{
Model Penjelasan Intensi Cerai Perempuan Muslim di Sulawesi Selatan
}

\author{
Asniar Khumas ${ }^{1}$ \\ Fakultas Psikologi Universitas Negeri Makassar
}

\author{
Johana E. Prawitasari ${ }^{2}$ \\ LPPM Universitas Kristen Krida Wacana, \\ (UKRIDA) Jakarta
}

\author{
Sofia Retnowati, Rahmat Hidayat \\ Fakultas Psikologi \\ Universitas Gadjah Mada
}

\begin{abstract}
The study tested the explanatory model of intentions for divorce based on the theory of social exchange, theory of planned behavior by Ajzen and model of dissolution by Amato and Rogers. The 197 subjects participating in this study were wives who had filed for divorce at the religious courts in several districts and cities in South Sulawesi. The measuring tools of the study were divorce intention scale and marital relationship scale developed by the researcher based on theoretical constructs of each tested factor. The theoretical model developed was tested with analysis of Structural Equation Models (SEM). The results of the study revealed that the intentions of divorce could be explained by the strong effects of negative relationships such as domestic violence, infidelity and irresponsibility. It was also found that there were weak barriers to divorce and post-divorce expectation of a better life with new partner who could love them more. Indirect factor that contributed to divorce intention was level of education. These findings confirmed the explanatory models of divorce intention based on social exchange theory, planned behavior theory, and the suggested Amato and Rogers' divorce models.
\end{abstract}

Keywords: divorce, intentions, moslem, women

Abstrak. Penelitian ini menguji model eksplanatori intensi cerai berdasarkan teori pertukaran sosial (social exchange theory), teori perilaku terencana dan model perceraian dari Amato dan Rogers. Sebanyak 197 partisipan dalam penelitian ini adalah istri yang mengajukan gugatan cerai di pengadilan agama (PA) di beberapa Kabupaten dan Kota di Sulawesi Selatan. Alat ukur penelitian terdiri dari skala intensi cerai dan hubungan perkawinan yang dikembangkan oleh peneliti berdasarkan konstruk teoritis masing-masing faktor yang diuji. Model teoritis yang dikembangkan diuji dengan analisis Structural Equation Model (SEM). Hasil analisis data penelitian nenunjukkan bahwa intensi cerai dapat dijelaskan oleh kuatnya daya tarik hubungan negatif dalam perkawinan, misalnya adanya kekerasan dalam rumah tangga, ketidaksetiaan, dan ketiadaan tanggungjawab. Juga ditemukan bahwa ada hambatan bercerai yang lemah dan keyakinan hidup lebih baik setelah bercerai yaitu ada harapan mendapatkan pasangan baru yang mencintai mereka. Faktor tidak langsung yang turut berkontribusi pada intensi cerai adalah tingkat pendidikan. Hasil temuan ini mengukuhkan model penjelasan intensi cerai berdasarkan teori pertukaran sosial, teori perilaku terencana dan model perceraian Amato dan Rogers yang diajukan.

Kata kunci: perceraian, intensi, perempuan, muslim

\footnotetext{
${ }^{1}$ Korespondensi mengenai isi artikel ini dapat dilakukan melalui: asniarkhumas@unm.ac.id

2 Atau melalui: jeprawitasari@ukrida.ac.id
} 
Angka perceraian dari tahun ke tahun menunjukkan kecenderungan meningkat. Kementerian Agama Republik Indonesia melaporkan bahwa pada tahun 2009 tercatat sebanyak 250.000 kasus perceraian terjadi di Indonesia. Angka ini setara dengan $10 \%$ dari 2,5 juta jumlah pernikahan di tahun 2009. Jumlah perceraian pada tahun 2009 naik 50 ribu kasus dibanding tahun 2008 yang mencapai 200 ribu kasus perceraian. Fakta lain dari kasus perceraian yang tercatat menunjukkan adanya pergeseran bentuk perceraian. Sekitar 70 persen perceraian yang terjadi di Pengadilan Agama (PA) adalah cerai gugat atau perceraian yang diajukan oleh istri (www.esqmaqazine.com).

Peningkatan angka perceraian dari tahun ke tahun menimbulkan konsekuensi yang serius dalam keluarga. Konflik selama proses perceraian dan perpisahan orang tua membawa dampak negatif pada kesejahteraan fisik dan psikologis seluruh anggota keluarga. Cukup banyak hasil penelitian menunjukkan bahwa perceraian membawa efek negatif pada semua anggota keluarga, terutama anak. Hasil metaanalisis Amato (2001) terhadap 67 hasil studi yang telah dipublikasikan pada dekade 1990-an menunjukkan bahwa anak-anak dari keluarga bercerai memiliki prestasi akademik, perilaku, penyesuaian psikologis, konsep diri dan relasi sosial yang lebih rendah dibanding anak-anak dari keluarga utuh. Penelitian Dong, et al. (2003) di Cina menunjukkan bahwa kemampuan penyesuaian diri anak-anak korban cerai lebih rendah dibanding anakanak dari keluarga utuh. Anak-anak dari keluarga bercerai menunjukkan tingkat kecemasan yang lebih tinggi serta mereka mengalami masalah perilaku (misalnya: perilaku kenakalan dan agresivitas, serta gangguan perhatian) bila dibandingkan dengan anak-anak dari keluarga yang mempunyai orang tua lengkap.

Perceraian merupakan peristiwa yang sangat menekan. Selain membawa dampak buruk pada anak, perceraian berdampak besar pada kelangsungan hidup suami istri yang mengalaminya. Pasangan yang bercerai cukup banyak yang mengunjungi klinik psikiatri dan rumah sakit daripada pasangan dari keluarga utuh. Pasangan bercerai lebih banyak yang mengalami kecemasan, depresi, perasaan marah, perasaan tidak kompeten, penolakan, dan kesepian (Gahler, 2006).

Berdasarkan studi empiris, berakhirnya perkawinan juga membawa beberapa dampak sosial, misalnya: mempersempit jaringan sosial yang berdampak pada kurangnya dukungan sosial, menyebabkan pengalaman hidup negatif dan penderitaan psikologis, serta menyebabkan kesulitan ekonomi bagi perempuan (Johnson \& Wu, 2002; Lorenz et al., 1997; Holden \& Smock, 1991; Kelly, 1989; Kitson \& Morgan, 1990; Raschke, 1987; Simons, Johnson, \& Lorenz, 1996). Penelitian kualitatif Salinah (2004) terhadap 10 perempuan yang mengajukan gugatan cerai di PA Banjarmasin menunjukkan bahwa dengan cerai gugat, pihak perempuan (istri) makin berada dalam posisi yang dirugikan. Hal ini disebabkan oleh bentuk perceraian adalah khuluk, yaitu perceraian terjadi dengan pembayaran tebusan (iwadh) dari istri dan tidak ada biaya hidup (nafkah iddah) serta membayar semua biaya perceraian.

Faktor-faktor apa yang menyebabkan perceraian? Pertanyaan ini dapat dijawab berdasarkan hasil penelitian empiris di berbagai Negara. Sebagai contoh, penelitian survei Amato dan Previti (2003) terhadap 208 partisipan (laki-laki dan 
perempuan) yang baru saja bercerai di Amerika Serikat menghasilkan 18 kategori sebab perceraian. Delapan belas kategori tersebut adalah sebagai berikut: (1) perselingkuhan/ketidaksetiaan, (2) ketidakcocokan, (3) mengkonsumsi Narkoba atau Alkohol, (4) percekcokan, (5) masalah kepribadian (6) masalah komunikasi, (7) kekerasan fisik atau psikis, (8) kehilangan perasaan cinta, (9) kurang bertanggung jawab terhadap keluarga (10) masalah pekerjaan (11) tidak tahu sebab perceraian (12) perkawinan tidak bahagia (13) masalah keuangan (14) sakit fisik atau mental (15) pertumbuhan pribadi (16) campur tangan keluarga (17) ketidakmatangan dan (18) sebab-sebab lain. Dari 18 kategori tersebut, perempuan melaporkan perselingkuhan, kekerasan fisik dan psikis serta konsumsi alkohol atau obat-obatan sebagai penyebab perceraian yang paling dominan.

Penelitian yang dilakukan Chang (2003) bahwa wanita imigran Korea yang bercerai disebabkan oleh kekerasan/perilaku negatif dari suami dan kesulitan keuangan dalam rumah tangga. Perempuan non-Korea melaporkan alasan abstrak dan afeksi. Pola alasan bercerai yang diungkapkan perempuan dalam penelitian ini berhubungan dengan kesulitan hidup yang dialami perempuan pasca bercerai.

Aghajanian dan Moghadas (1998) melakukan telaah sebab perceraian di Iran dalam tiga dekade terakhir melaporkan bahwa perempuan Iran yang bercerai mengalami kesulitan keuangan dan mengalami persoalan psikologis dalam perjalanan perkawinan. Penelitian Zargar dan Doost (2008) di Falavarjan, Iran, menemukan persoalan komunikasi dalam rumah tangga, adiksi atau ketergantungan terhadap alkohol atau obat-obatan, campur tangan anggota keluarga/pihak ketiga dan gangguan mental salah satu atau keduanya merupakan faktor penyebab penting perceraian yang dilaporkan oleh partisipan penelitian. Khusus untuk sebab cerai gugat di Sulawesi Selatan, berdasarkan telaah terhadap 104 kasus gugat cerai istri di PA Makassar pada bulan Maret 2011 diketahui bahwa faktor utama yang menyebabkan istri berniat cerai adalah: kekerasaan fisik dan psikis, perselingkuhan atau poligami yang dilakukan suami, kurangnya tanggungjawab suami dalam memberi nafkah pada istri dan anak serta komunikasi yang buruk bahkan terputus dalam perkawinan.

Bagaimana keputusan untuk mengajukan cerai gugat diambil oleh perempuan muslim di Indonesia, khususnya di Sulawesi Selatan? Tingginya angka cerai gugat (gugatan untuk bercerai dari istri) dibanding cerai talak (gugatan untuk bercerai dari suami) mengisyaratkan bahwa terjadi persoalan mendasar dalam hubungan perkawinan. Perkawinan yang diharapkan dapat membentuk keluarga tenteram, penuh cinta dan kasih sayang tidak berjalan sebagaimana yang diharapkan oleh pihak istri.

Pada dasarnya, pembahasan mengenai ikatan perkawinan yang berakhir dengan perceraian tidak dapat dilepaskan dari upaya untuk memahami bagaimana hubungan suami istri dalam ikatan tersebut berkembang dan memengaruhi perilaku masing-masing pasangan (Reis, Collins, \& Berscheid, 2000). Apakah relasi yang terbentuk dirasakan seimbang? Apakah hubungan suami istri bergerak dari tahap permukaan menuju tahap yang lebih dalam sehingga meningkatkan kebahagiaan dan komitmen masing-masing pribadi, atau sebaliknya, hubungan yang terbentuk cenderung timpang sehingga membawa penderitaan yang menimbulkan keterasingan (alienasi) satu sama lain yang bermuara pada perceraian? 
Untuk menjawab pertanyaan yang diajukan, ada dua kondisi yang mencerminkan perjalanan perkawinan pasangan suami istri. Pertama, perkawinan tetap bertahan karena hal-hal menyenangkan yang menjadi dasar perkawinan yaitu yang bersifat fisik maupun psikis masih dirasakan. Kondisi ini menjadi daya tarik positif perkawinan menurut teori pertukaran sosial (Andersen, 2001) atau dalam teori perilaku terencana (Armitage \& Conner, 2005), hal-hal positif yang dirasakan akan membentuk sikap positif terhadap perkawinan.

Kondisi kedua, perjalanan perkawinan berakhir pada perceraian karena hilangnya daya tarik positif perkawinan. Relasi yang terjalin dalam perkawinan membawa penderitaan atau sikap negatif terhadap perkawinan. Berikut ini adalah hasil-hasil penelitian yang menunjukkan bahwa relasi yang terjalin dalam perkawinan menimbulkan beban atau penderitaan terhadap istri, antara lain pihak istri mengalami kekerasan fisik, verbal, dan seksual dalam rumah tangga (Asmarany, 2008; Nadia, 1998; Wolcott \& Hughes, 1999; Fadjaryana, 2004; Zakiyah, 2005; Maryati, 2007; Amato \& Previti, 2003; DeMaris, 2000; Rogge \& Bradbury, 1999; Shortt et al., 2006). Adanya situasi yang menunjukkan kurang tanggung jawab, misalnya istri dan anak tidak dinafkahi (Wolcott \& Hughes, 1999; Amato \& Previti, 2003), ada penghianatan suami yang berselingkuh (Hall \& Fincham, 2006; Wolcott \& Hughes, 1999; Amato \& Previti, 2003; Fan \& Lui, 2004), atau suami melakukan poligami (Fadjaryana, 2004; Zakiyah, 2005; Maryati, 2007).

Selain daya tarik utama yaitu adanya kondisi yang telah disebut sebelumnya, ada daya tarik lain yang memengaruhi perceraian, yaitu, daya tarik alternatif. Adanya alternatif kehidupan yang lebih baik setelah bercerai merupakan proses yang terjadi dalam keputusan cerai perempuan menurut teori pertukaran sosial (Anderson, 2001). Daya tarik alternatif mencakup menikah kembali dengan pasangan yang berbeda, membentuk sebuah hubungan yang lebih informal dengan pasangan lain, atau tetap sendiri dan berkomitmen untuk tidak menikah (dalam Knoester \& Booth, 2000). Daya tarik alternatif sebagai salah satu alasan bercerai perempuan merupakan faktor kontrol terhadap perilaku sehingga sangat berkaitan dengan keyakinan mudah atau tidaknya perceraian diwujudkan dalam pandangan teori perilaku terencana (Krueger \& Dickson, 1994).

Apabila merujuk pada pandangan Levinger (dalam Previti \& Amato, 2003; Amato \& Marriot, 2007; Bodenmann et al., 2006), ada faktor-faktor yang dapat memengaruhi kemantapan hati seseorang dalam memutuskan perceraian. Faktor-faktor tersebut dapat menjadi penghalang (barrier) bagi niat cerai pasangan suami istri, diantaranya: tanggung jawab terhadap anak dan keluarga besar, keyakinan terhadap ajaran agama, kekhawatiran tidak mampu hidup dengan layak karena ketergantungan finansial atau kehilangan tempat tinggal dan kekuatiran terhadap stigma sosial (dalam Previti \& Amato, 2003).

Selanjutnya, hasil telaah terhadap alasan cerai dari kasus yang telah dipaparkan dan hasil-hasil penelitian yang mendukungnya menunjukkan bahwa alasan perceraian yang diajukan istri merupakan persoalan-persoalan yang muncul dalam perkawinan. Alasan tersebut merupakan faktor yang berpengaruh langsung terhadap perceraian atau disebut Amato dan Rogers (1997) sebagai proximal causes. Alasan gugatan cerai tersebut berasal dari pengalaman buruk yang dialami istri selama perkawinan (White, 1990). 
Faktor lain yang turut berpengaruh terhadap terjadinya perceraian adalah faktor tidak langsung, disebut distal causes (Amato \& Rogers, 1997), misalnya: perceraian orangtua, usia saat menikah, tingkat pendidikan, dan status pekerjaan. Faktorfaktor tersebut dapat meningkatkan risiko perceraian (White, 1990). Faktor langsung dan tidak langsung yang menyebabkan perceraian didukung oleh penjelasan model perceraian Amato dan Rogers (1991).

Fishbein dan Ajzen (1975) mengemukakan bahwa intensi seseorang dapat berubah setiap waktu. Hal ini berarti bahwa niat istri untuk bercerai bisa berubah karena terjadi faktor-faktor tertentu yang dapat mengubah intensinya. Teori/model apa yang sesuai untuk menjelaskan intensi cerai istri yang sedang menggugat cerai di pengadilan? Berdasarkan paparan sebelumnya, intensi cerai istri dalam penelitian ini dijelaskan dengan membangun sebuah model yang didasari oleh teori pertukaran sosial, teori perilaku terencana dan model perceraian dari Amato dan Rogers. Model penjelasan yang menggabungkan ketiga teori/model tersebut dimaksudkan untuk mengeliminasi kelemahan dari masingmasing teori/model sehingga dapat saling melengkapi satu sama lain. Horn (dalam Ajzen, 1988) menjelaskan bahwa intensi adalah istilah yang terkait dengan tindakan dan merupakan unsur yang penting dalam sejumlah tindakan. Intensi menunjuk pada keadaan pikiran seseorang yang diarahkan untuk melakukan suatu tindakan, yang senyatanya dapat atau tidak dapat dilakukan, dan diarahkan pada tindakan sekarang atau tindakan yang akan datang. Pada penelitian ini, pengertian intensi adalah derajad kemantapan seseorang untuk mewujudkan suatu perilaku tertentu dengan upaya sungguhsungguh yang dilakukan.
Peneliti-peneliti di negara barat menggunakan istilah marital dissolution, divorce dan marital breakdown, secara bergantian pada saat membahas tentang perceraian. Marital dissolution (terputusnya pernikahan) merupakan istilah yang menunjuk pada dua kata atau pengertian, yaitu: perceraian (divorce) dan perpisahan (separate). Perceraian (divorce) dalam kamus Psikologi terbitan American Psychological Association (2007), berarti terputusnya ikatan perkawinan menurut hukum atau undang-undang; meninggalkan pasangan sehingga bebas untuk menikah lagi. Dengan demikian, dalam penelitian ini, pengertian intensi cerai adalah derajad kemantapan istri untuk mewujudkan putusnya hubungan suami istri dengan mengikuti semua prosedur hukum (undang-undang) yang berlaku di Indonesia.

Teori yang digunakan untuk menjelaskan intensi cerai perempuan adalah teori pertukaran sosial, teori perilaku terencana dan model perceraian Amato dan Rogers. Teori pertukaran sosial menjelaskan bahwa bentuk dan kualitas dari interaksi sosial seseorang didasarkan pada tingkatan kepuasan individu terhadap hubungan yang terjalin. Tingkatan kepuasan seseorang terhadap hubungan perkawinan merupakan hasil dari evaluasi individu terhadap imbalan dan beban yang dirasakan dari hubungan tersebut. Berdasarkan pandangan Levinger (dalam Wagner \& Weiss, 2004; Bodenmann et al., 2007), keputusan seseorang untuk bertahan dalam perkawinan tergantung dari daya tarik (attractor) terhadap perkawinan, daya tarik alternatif, dan rintangan (barrier) dalam bercerai (Previti \& Amato, 2003; Wagner \& Weiss, 2004; Amato \& Marriot, 2007; Bodenmann et al., 2007). Ketiga faktor tersebut sama pentingnya sehingga menjelaskan fenomena perce- 
raian dengan menggunakan salah satu dari ketiga istilah tersebut tidak cukup.

Teori perilaku terencana (theory of planned behavior) dari Ajzen (Ajzen, 2005) merupakan pengembangan dari teori perilaku beralasan (theory of reasoned action). Tiga faktor yang merupakan determinan konseptual intensi berperilaku menurut teori perilaku terencana (Ajzen, 2005): (a) sikap terhadap perilaku (attitude toward behavior) merupakan tingkatan dimana seseorang mempunyai penilaian setuju/ bersikap positif atau tidak setuju/bersikap negatif terhadap perilaku tertentu; (b) norma partisipantif (subjective norm) merupakan tekanan sosial yang dirasakan untuk mewujudkan perilaku atau tidak; (c) kontrol perilaku yang dirasakan (perceived behavioral control) merupakan perasaan mudah atau sulit mewujudkan perilaku. Konsep ini dikenalkan dalam teori perilaku terencana untuk mengakomodasi aspek/elemen non-volisional.

Model perceraian dari Amato dan Rogers (1997) menunjukkan bahwa selain faktor langsung yang memengaruhi intensi cerai, terdapat juga faktor tidak langsung. Persoalan-persoalan yang muncul dalam perkawinan atau disebut proximal causes, merupakan faktor yang berpengaruh langsung terhadap perceraian. Faktor lain yang turut berpengaruh terhadap perceraian, misalnya: perceraian orangtua, usia saat menikah, tingkat pendidikan, pekerjaan, kepribadian, dan ketaatan pada perintah agama menurut Amato dan Rogers (1997) merupakan faktor tidak langsung (distal causes) yang dapat meningkatkan risiko perceraian (White, 1990).

Gambar 1 adalah model eksplanatori intensi cerai yang dikembangkan menurut teori pertukaran sosial, teori perilaku terencana dan model perceraian dari Amato dan Rogers.
Tujuan penelitian ini adalah menguji model eksplanatori intensi cerai berdasarkan teori pertukaran sosial, teori perilaku terencana dan model perceraian dari Amato dan Rogers untuk mengetahui prediktor-prediktor intensi cerai, baik yang berpengaruh secara langsung, maupun tidak langsung. Untuk itu diajukan hipotesis mayor dan minor.

\section{Hipotesis Mayor}

Intensi cerai dipengaruhi oleh daya tarik negatif hubungan perkawinan, keyakinan hidup lebih baik pasca bercerai dan hambatan bercerai serta faktor tidak langsung yaitu usia saat menikah, tingkat pendidikan, status pekerjaan dan status perkawinan orang tua.

\section{Hipotesis Minor}

Hipotesis Minor yang diajukan pada penelitian ini sebagai berikut; (1) Daya tarik negatif hubungan perkawinan (tidak setia, kekerasan dalam rumah tangga dan tidak bertanggungjawab) berpengaruh terhadap Intensi cerai perempuan, (2) Hambatan bercerai berpengaruh terhadap intensi cerai perempuan, (3) Keyakinan hidup lebih baik setelah bercerai berpengaruh terhadap intensi cerai perempuan, (4) Usia saat menikah berpengaruh terhadap intensi cerai perempuan, (5) Tingkat pendidikan berpengaruh terhadap intensi cerai perempuan, dan (6) Status Pekerjaan berpengaruh terhadap intensi cerai perempuan.

\section{Metode}

\section{Partisipan Penelitian}

Sebanyak 197 orang istri yang sedang menggugat cerai terlibat sebagai partisipan penelitian. Pengambilan sampel dalam penelitian ini menggunakan purposive sampling. 


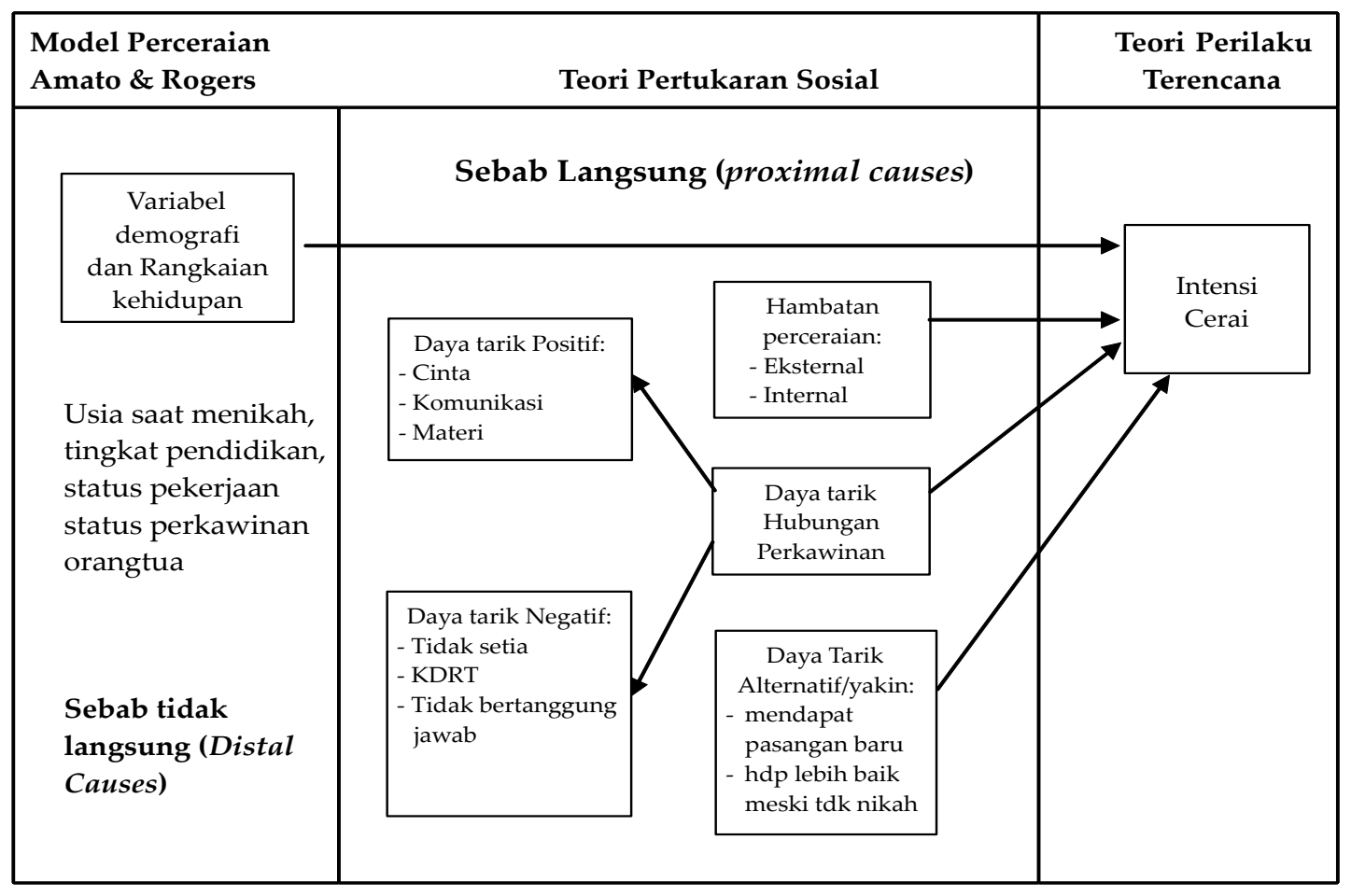

Gambar 1. Model eksplanatori intensi cerai perempuan Indonesia

Pengumpulan data penelitian dilakukan dengan menggunakan skala psikologis dan kuesioner. Skala yang digunakan dalam penelitian terdiri dari skala intensi cerai dan skala hubungan perkawinan yang mengukur faktor-faktor sebagai berikut: daya tarik perkawinan, meliputi dimensi daya tarik hubungan positif dan negatif, keyakinan hidup lebih baik setelah bercerai dan hambatan bercerai. Masingmasing skala akan mengungkap konstrak teoritis dari masing-masing faktor yang diukur dengan mengacu pada pandangan tokoh-tokoh yang banyak meneliti faktorfaktor yang akan diungkap.

\section{Definisi Operasional Variabel Penelitian}

Intensi cerai. Intensi cerai adalah derajad kemantapan istri untuk mengakhiri ikatan hukum perkawinan sesuai aturan Undang-Undang Perkawinan yang berla$\mathrm{ku}$ di Indonesia. Intensi cerai istri diukur dengan skala yang terdiri dari sembilan aitem yang disusun oleh peneliti. Skor intensi cerai yang tinggi menunjukkan kemantapan istri untuk mewujudkan perceraian. Sebaliknya, apabila skor intensi cerai rendah, diartikan bahwa kemantapan hati istri untuk bercerai rendah.

Daya tarik hubungan positif. Daya tarik hubungan positif merupakan hal yang menyenangkan yang dirasakan dalam hubungan perkawinan. Daya tarik hubungan positif yang diukur dalam penelitian ini adalah: (a) Faktor materi, yaitu terpenuhinya kebutuhan sehari-hari seluruh anggota keluarga. Indikator faktor ini meliputi pemenuhan kebutuhan pokok dan sekunder diukur dengan tiga aitem dalam skala yang disusun peneliti, (b) Faktor cinta, yaitu ada perasaan kuat dan kasih sayang dalam bentuk: komitmen, intimacy (perasaan dekat) atau keinginan membahagiakan, senang bila bersama, saling mendukung secara emosional, dan menghargai atau perasaan akrab/bersahabat (companiate) dan passion (dorongan untuk romantis dan ada unsur dorongan 
untuk berhubungan seksual). Faktor ini terdiri dari sembilan aitem dalam skala yang disusun peneliti, dan (c) Faktor komunikasi merupakan proses penyampaian pikiran, ide, atau pesan antar suami istri. Faktor ini terdiri dari tujuh aitem dalam skala yang disusun oleh peneliti.

Daya tarik hubungan negatif. Daya tarik hubungan negatif merupakan hal-hal yang tidak menyenangkan dalam hubungan perkawinan. Ada tiga faktor yang akan diukur dalam penelitian ini, yaitu: (a) Faktor kekerasan terhadap istri, merupakan perilaku suami yang menimbulkan penderitaan fisik dan psikis pada istri. Faktor ini diukur dengan tujuh aitem dalam skala yang disusun oleh peneliti. (b) Faktor ketidaksetiaan merupakan hubungan seksual, romantis atau keterlibatan emosi suami dengan perempuan lain, baik secara formal dengan menikah lagi, atau tidak sehingga menghancurkan kepercayaan istri. Faktor ini diukur dengan empat aitem dalam skala, dan (c) Faktor melalaikan tanggungjawab adalah perilaku yang mengabaikan kepentingan pasangan dan anggota keluarga lainnya. Faktor ini diukur dengan skala dengan jumlah enam aitem.

Keyakinan hidup. Keyakinan hidup lebih baik setelah bercerai merupakan tingkat kepastian akan menjalani hidup lebih baik setelah bercerai. Akan diukur dengan empat aitem dalam skala. Apabila skor keyakinan hidup lebih baik setelah bercerai cenderung tinggi maka dapat disimpulkan bahwa istri akan memutuskan hubungan perkawinan. Sebaliknya, apabila skor keyakinan hidup lebih baik setelah bercerai tergolong rendah, maka istri cenderung akan bertahan dalam hubungan perkawinan.

Hambatan bercerai. Hambatan bercerai merupakan faktor-faktor yang mencegah berakhirnya perkawinan, yang meliputi: persoalan ekonomi dan kebimbangan karena keyakinan atau ajaran agama yang tidak menganjurkan perceraian. Hambatan bercerai diukur dengan tiga aitem dalam skala yang disusun oleh peneliti. Apabila skor hambatan bercerai tergolong tinggi, maka dapat disimpulkan bahwa istri akan mempertahankan perkawinan. Sebaliknya, apabila skor hambatan bercerai rendah, maka istri cenderung memutuskan hubungan perkawinan.

Usia saat menikah. Usia saat menikah, merupakan usia istri saat menikah pertama kali. Usia saat menikah akan diungkap dengan daftar isian berdasarkan pengelompokan usia sebagai berikut: (a) menikah sebelum usia 18 tahun (b) menikah pada usia $18-25$ tahun (c) menikah pada usia 26 - 30 tahun (d) menikah pada usia 31 - 35 tahun (e) menikah pada usia 36 - 40 tahun.

Tingkat pendidikan. Tingkat pendidikan merupakan jenjang pendidikan formal yang pernah diikuti. Tingkat pendidikan diungkap dengan daftar isian yang meliputi: (a) tidak pernah sekolah, (b) SD, (c) SMP (d) SMA, dan (e) Perguruan Tinggi, meliputi: D1 - D2 - D3 - D4 - S1 - S2 - S3.

Status pekerjaan. Status pekerjaan, merupakan aktivitas bekerja yang dilakukan istri di dalam maupun di luar rumah. Status pekerjaan akan diungkap melalui daftar isian dengan pengelompokan tidak bekerja dan bekerja penuh waktu dengan jenis pekerjaan meliputi: Bekerja di wilayah domestik, misalnya Pekerja Rumah Tangga-Pegawai Negeri SipilPekerja Swasta-Wiraswasta/usaha mandiri Profesional, misalnya pengacara, dokter, akuntan publik, dan psikolog.

Status perkawinan. Status perkawinan orang tua merupakan sejarah perkawinan orang tua pada masa lalu hingga saat ini. Status perkawinan orang tua diungkap melalui daftar isian dengan penge- 
lompokan: (a) Perkawinan orang tua bertahan sejak dulu hingga saat ini, (b) Orang tua bercerai dan salah satunya menikah lagi, dan (c) Ayah dan Ibu bercerai dan masing-masing menikah lagi.

\section{Proses Konstruksi Alat Ukur}

Pada tahap pertama, proses validasi alat ukur menggunakan uji validitas isi dengan pendekatan rasio validitas isi (Content Validity Ratio atau CVR). Uji CVR (Cohen, 2005) melibatkan beberapa ahli dalam bidang psikologi klinis, psikologi sosial, psikologi umum dan eksperimen, psikologi ekonomi, dan psikologi perkembangan. Jumlah aitem pada skala intensi cerai setelah uji CVR adalah sembilan aitem. Jumlah aitem pada skala hubungan perkawinan setelah uji CVR sebanyak 43 aitem. Alat ukur psikologis yang digunakan harus memenuhi persyaratan validitas dan reliabilitas. Langkah yang dilakukan setelah data uji coba terbatas diperoleh adalah melakukan pengujian konsistensi aitem atau dikenal sebagai indeks daya beda aitem dan pengujian reliabilitas. Pengujian reliabilitas akan dapat memberikan hasil yang relatif sama bila dilakukan pengukuran kembali terhadap partisipan yang sama (Azwar, 1997).

Selanjutnya, dilakukan pengujian validitas konstrak. Validitas konstrak menunjuk pada sejauh mana suatu alat ukur mengungkap konstrak teoritik yang menjadi dasar penyusunan skala (Azwar, 1997). Untuk membantu mengidentifikasi konstrak yang sifatnya tidak bisa diukur secara langsung (unobservable) digunakan analisis faktor (Gudono, 2011). Ada dua jenis analisis faktor yang ditempuh yaitu: analisis faktor eksploratori dan analisis faktor konfirmatori.

Analisis faktor eksploratori bertujuan untuk mengidentifikasi aitem yang digunakan, apakah suatu aitem dapat mengu- kur satu faktor atau pengelompokan aitem tersebut menjadi bagian dari faktor lain pada alat ukur yang disusun. Batasan nilai muatan faktor (loading factor) minimal pada analisis faktor eksploratori adalah 0,5 (Hair, 2006).

Setelah melakukan analisis faktor eksploratori, dilakukan analisis faktor konfirmatori. Analisis faktor konfirmatori bertujuan untuk menguji variabel terobservasi dalam model persamaan struktural. Analisis ini bertujuan untuk melakukan verifikasi secara empiris atau melakukan konfirmasi terhadap struktur faktor yang ada (Gudono, 2011).

Penelitian ini menguji peran usia saat menikah, tingkat pendidikan, status pekerjaan dan status perkawinan orangtua terhadap intensi cerai istri. Faktor-faktor tersebut diungkap melalui kuesioner. Kuesioner penelitian mengungkap identitas dan informasi-informasi lain untuk menjelaskan latar belakang partisipan penelitian yang meliputi: usia saat menikah, tingkat pendidikan, pekerjaan, status perkawinan orang tua, memiliki anak atau tidak dan jumlah anak yang dimiliki dan agama yang dianut.

\section{$\mathrm{H}$ a $\mathrm{s}$ i 1}

Model alternatif intensi cerai yang fit menunjukkan bahwa intensi cerai dapat dijelaskan oleh daya tarik negatif hubungan perkawinan (suami melakukan kekerasan, tidak setia dan tidak bertanggungjawab) hambatan bercerai dan keyakinan hidup lebih baik setelah bercerai. Faktor tidak langsung yang turut berkontribusi pada intensi cerai adalah tingkat pendidikan. Model penjelasan intensi cerai yang memiliki nilai goodness of fit memenuhi kriteria pada Gambar 2.

Selanjutnya, untuk menjawab hipotesis minor penelitian yang diajukan, maka 


\section{KHUMAS, DKK}

hasil estimasi bobot regresi model terdapat pada Tabel 1.

Berdasarkan estimasi pengaruh dari masing-masing variabel dalam model diperoleh hasil sebagai berikut:

Hipotesis Minor 1: Berdasarkan model yang fit, daya tarik negatif perkawinan dapat menjelaskan intensi cerai dan pengaruhnya signifikan (nilai estimasi 0,$424 ; p=0,049, p<0,05)$.
Hipotesis Minor 2: Berdasarkan model yang fit, hambatan bercerai (faktor keyakinan menurut ajaran Islam bahwa bercerai menjauhkan diri dari surga) dapat menjelaskan intensi cerai dan berpengaruh sangat siginifikan (nilai estimasi -0,248; $p<0,001)$. Nilai negatif pada hasil estimasi pengaruh hambatan bercerai menunjukkan bahwa semakin rendah hambatan bercerai, semakin kuat intensi cerai perempuan.

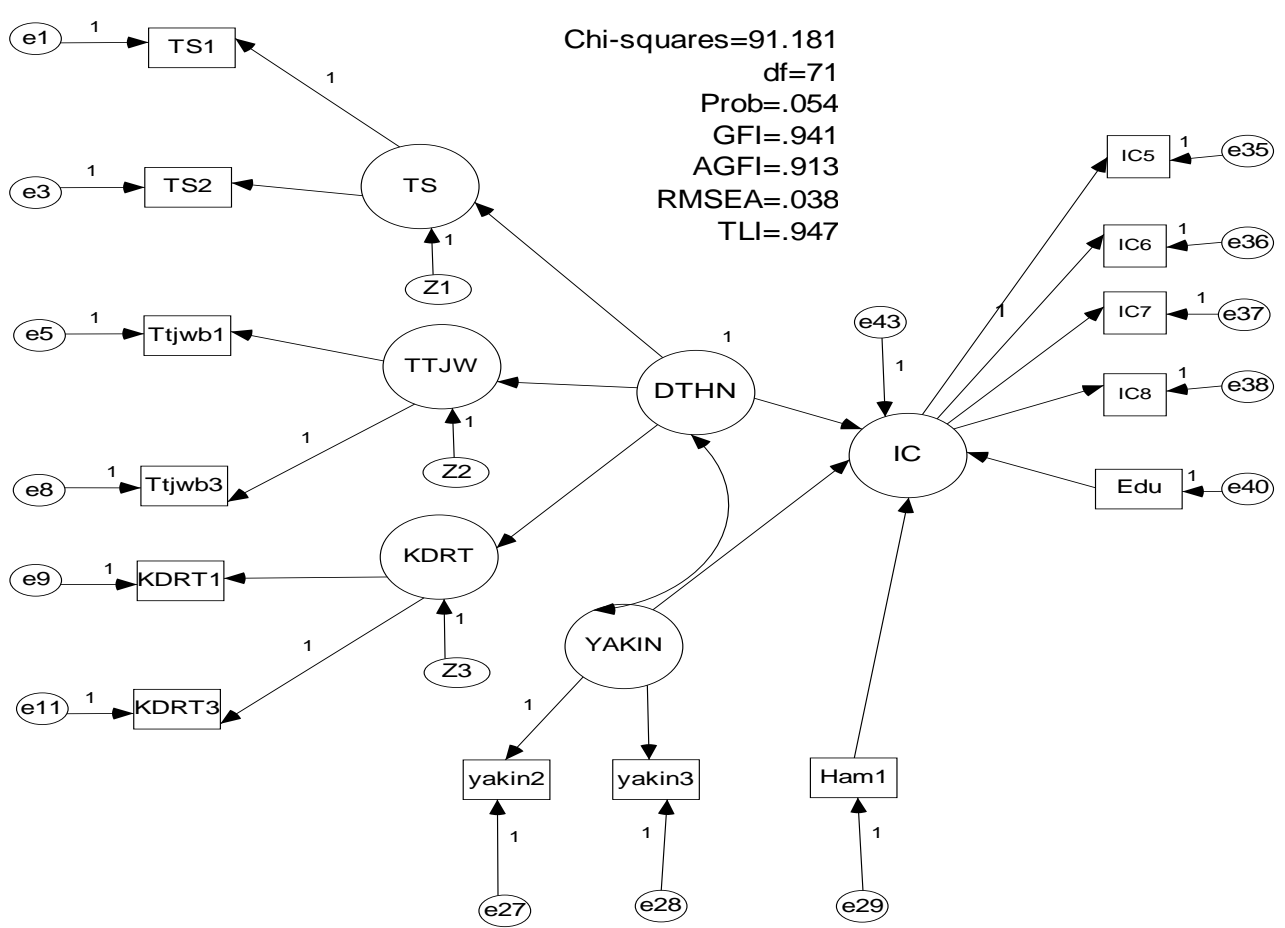

Gambar 2. Model Intensi Cerai Modifikasi yang fit

Tabel 1

Estimasi Bobot Regresi Hasil Analisis Model Intensi Cerai Modifikasi

\begin{tabular}{cccccc}
\hline Variabel & $\begin{array}{c}\text { Estimasi Bobot } \\
\text { Regresi }\end{array}$ & $\begin{array}{c}\text { Estimasi Bobot } \\
\text { Regresi Terstandar }\end{array}$ & $\begin{array}{c}\text { Standar Kesalahan } \\
\text { Pengukuran }\end{array}$ & $\begin{array}{c}\text { Nilai } \\
\text { Kritis }\end{array}$ & $p$ \\
\hline IC $\leftarrow$ DTHN & 0,424 & 0,306 & 0,215 & 1,971 & 0,049 \\
IC $\leftarrow$ YAKIN & 0,824 & 0,347 & 0,408 & 2,019 & 0,043 \\
IC $\leftarrow$ HAM1 & $-0,248$ & $-0,280$ & 0,070 & 2,164 & $* * *$ \\
IC $\leftarrow$ Edu & $-0,112$ & $-0,170$ & 0,052 & -3.555 & 0,030 \\
\hline
\end{tabular}


Hipotesis Minor 3: Berdasarkan model yang fit, keyakinan hidup lebih baik setelah bercerai (menemukan pasangan baru yang lebih baik) dapat menjelaskan intensi cerai dan pengaruhnya signifikan (nilai estimasi 0,824; $p=0,043, p<0,05)$.

Hipotesis Minor 4: Berdasarkan model yang fit, usia saat menikah tidak dapat menjelaskan pengaruhnya terhadap intensi cerai.

Hipotesis Minor 5: Berdasarkan model yang fit, tingkat pendidikan dapat menjelaskan intensi cerai dan berpengaruh signifikan (nilai estimasi $-0,112 ; p=0,030, p<0,05)$. Nilai negatif pada hasil estimasi pengaruh pendidikan pada intensi cerai menunjukkan bahwa semakin tinggi tingkat pendidikan maka intensi cerai semakin rendah.

Hipotesis Minor 6: Berdasarkan model yang fit, status pekerjaan tidak dapat menjelaskan pengaruhnya terhadap intensi cerai.

Hipotesis Minor 7: Berdasarkan model yang fit, status perkawinan orangtua tidak dapat menjelaskan intensi cerai perempuan.

\section{Diskusi}

Berdasarkan hasil analisis data penelitian terhadap 197 partisipan penelitian, ditemukan bahwa model penjelasan intensi cerai perempuan dipengaruhi oleh daya tarik negatif hubungan perkawinan, yaitu apabila isteri mengalami kekerasan dalam rumah tangga dan menghadapi kenyataan bahwa suami tidak setia, serta suami tidak bertanggungjawab,. Intensi bercerai tersebut diiringi oleh keyakinan kuat bahwa isteri akan mendapat pasangan baru apabila bercerai. Faktor keyakinan terhadap ajaran agama (khususnya Islam) yang diduga dapat menghambat perceraian ternyata tidak berlaku demikian. Ajaran agama Islam yang menyatakan bahwa perceraian akan menjauhkan diri dari surga tidak menjadi penghambat untuk bercerai, sehingga intensi cerai istri tetap tinggi. Faktor tidak langsung yang turut berkontibusi terhadap intensi cerai berdasarkan model yang fit adalah faktor pendidikan. Semakin tinggi tingkat pendidikan seorang istri, intensi cerainya akan semakin rendah.

Model intensi cerai yang ditemukan mengukuhkan model penjelasan intensi cerai berdasarkan teori pertukaran sosial (Ksopowa, 1998; Wolcott \& Hughes, 1999; Andersen, 2001; South et al., 2001; Sweeney, 2002; Wagner \& Weiss, 2002; Wagner \& Weiss, 2004; Cooke, 2006; Fu, 2006; Previti \& Amato, 2003; Knoester \& Booth, 2000; Bodenmann et al., 2006; Bulanda \& Brown, 2006; Clarkwest, 2007; Bachman \& Guerrero 2006), teori perilaku terencana (Ajzen, 1988; Horn (dalam Honderick, 1995) dan model perceraian Amato dan Rogers (1997) yang diajukan. Ketiga teori tersebut saling melengkapi dalam menjelaskan intensi cerai yang dirasakan perempuan.

Dinamika psikologis model penjelasan intensi cerai ini dapat dijelaskan sebagai berikut. Perceraian dengan segenap implikasinya pada semua aspek kehidupan (pengasuhan, ekonomi, sosial, legal dan patologi) merupakan keputusan berat bagi seorang perempuan. Kemantapan perempuan untuk bercerai diakibatkan oleh hilangnya daya tarik positif dalam hubungan perkawinan. Hal tersebut didukung oleh kenyataan bahwa mayoritas partisipan memiliki rasa cinta yang tergolong rendah, komunikasi yang kurang berjalan baik, dan kurang terpenuhi kebutuhannya dalam hal materi. Intensi untuk bercerai apakah itu kuat atau lemah 
yang dipengaruhi oleh berbagai faktor dapat terjawab dalam penelitian ini.

Penelitian Stanley et al. (2002) dalam survei nasional di Amerika Serikat, menemukan bahwa potensi bercerai akan sangat kuat apabila koneksi positif, yaitu aspek komunikasi dan komitmen tidak mendukung atau dalam perkawinan sangat rendah bahkan tidak dirasakan lagi oleh perempuan. Pandangan tersebut diperkuat oleh temuan Graaf dan Kalmijn (2006) di Belanda yang menemukan bahwa kecenderungan motif perceraian yang dirasakan perempuan adalah motif relasional dan psikologis (sering berselisih, tidak memberi perhatian pada istri dan tidak berkomunikasi lagi).

Salah satu kekuatan penelitian ini adalah penyertaan faktor daya tarik positif sebagai salah satu dimensi dari teori pertukaran sosial untuk diuji. Pada penelitian-penelitian terdahulu, dimensi daya tarik positif tidak pernah turut diuji pengaruhnya terhadap dinamika sebab perceraian yang terjadi (dalam English, 1997).

English (1997) menyatakan bahwa pada penelitian yang bersifat retrospektif, partisipan cenderung atau hanya melaporkan daya tarik negatif atau beban (cost) karena perceraian telah lama terjadi. Dengan demikian, titik fokus penelitian yang meneliti perempuan yang sedang dalam proses perceraian menunjukkan bahwa konsep intensi yang merupakan konsep teori perilaku terencana relevan dan teruji dalam penelitian ini.

Selanjutnya, daya tarik negatif sebagai faktor yang cukup berpengaruh dalam model intensi cerai ini dapat dijelaskan sebagai berikut: mayoritas partisipan penelitian merasakan suami kurang bertanggung jawab dan merasa dikhianati oleh suami. Hal ini sejalan dengan temuan-temuan penelitian perceraian yang bersifat retrospektif yang menemukan bahwa lemahnya tanggung jawab suami terhadap istri dan anak atau suami tidak menafkahi (Wolcott \& Hughes, 1999; Amato \& Previti, 2003) dan menghadapi penghianatan suami yang berselingkuh (Hall \& Fincham, 2006; Wolcott \& Hughes, 1999; Amato \& Previti, 2003; Fan \& Lui, 2004) atau melakukan poligami (Fadjaryana, 2004; Zakiyah, 2005; Maryati, 2007) merupakan sebab-sebab perceraian yang dominan diungkapkan perempuan. Sebanyak 116 partisipan penelitian (58 partisipan pada taraf sedang dan 58 partisipan pada taraf sering) melaporkan mengalami kekerasan dari suami (Wolcott \& Hughes, 1999; Fadjaryana, 2004; Amato \& Previti, 2003; DeMaris, 2000; Rogge \& Bradbury, 1999; Shortt et al., 2006) sebagai alasan yang menyebabkan intensi cerai mereka tergolong tinggi. Penelitian yang dilakukan Chang (2003) melaporkan bahwa wanita imigran Korea yang bercerai disebabkan oleh kekerasan/perilaku negatif dari suami dan kesulitan keuangan dalam rumah tangga.

Dengan demikian, perkawinan yang berjalan tidak bahagia menyebabkan intensi cerai istri menjadi sangat kuat. Hasil penelitian ini mendukung temuan penelitian pada istri yang mengukur perkawinan yang dijalaninya berjalan tidak bahagia dapat memprediksi akan berakhir dengan perceraian (Nock, 2001).

Keyakinan untuk hidup lebih baik setelah bercerai, khususnya memeroleh pasangan baru merupakan salah satu faktor yang memengaruhi kemantapan perempuan untuk bercerai. English (1997), dalam penelitiannya menemukan bahwa perempuan lebih optimis terhadap masa depan yang lebih baik dan akan mendapatkan hubungan yang lebih memuaskan dari anggota keluarga lain atau temanteman setelah bercerai. 
Hasil penelitian ini juga mendukung temuan South et al. (2001) yang melakukan penelitian dengan menggabungkan data sejarah pernikahan partisipan dan data sensus yang menggambarkan komposisi jenis kelamin dari bursa pernikahan lokal dan pekerjaan untuk meneliti pengaruh keberadaan daya tarik pasangan alternatif terhadap perceraian. Model regresi risiko proporsional mengungkapkan bahwa risiko cerai tertinggi berada pada bursa pernikahan geografis di mana baik suami maupun istri menemukan banyak alternatif pasangan. Pasangan juga lebih cenderung bercerai ketika istri bekerja di pekerjaan di mana pria relatif banyak dan wanita sedikit. Bloom et al. (1985) dalam penelitiannya terhadap mayoritas perempuan menemukan bahwa pertumbuhan pribadi, meningkatnya kebahagiaan, kebebasan dan terlepas dari konflik sebagai bentuk alternatif dari perceraian yang terjadi.

Temuan yang berkaitan dengan hambatan bercerai menunjukkan nilai estimasi regresi model untuk faktor hambatan bercerai ditemukan berarah negatif. Hal ini dikarenakan hambatan bercerai merupakan faktor yang sifatnya unfavorable. Dengan demikian, hambatan bercerai yang berkaitan dengan faktor keyakinan terhadap ajaran agama Islam yang menyatakan bahwa orang yang bercerai akan jauh dari surga ternyata tidak menjadi penghambat istri dalam memutuskan perceraian. Temuan ini dapat dipahami dengan banyaknya hasil penelitian yang menunjukkan bahwa perceraian bisa menjadi salah satu solusi dari berbagai persoalan perkawinan yang mengancam kesejahteraan hidup pasangan suami istri.

Hawkins dan Booth (2005), dalam penelitian longitudinal di Amerika Serikat menemukan bahwa perkawinan yang tidak bahagia akan membawa efek negatif pada kesejahteraan (well-being) suami istri bila dipertahankan. Pasangan yang mempertahankan perkawinan yang tidak bahagia merasakan efek lebih buruk daripada pasangan yang bercerai dan menikah kembali dalam hal kepuasan hidup, harga diri, dan kesehatan fisik serta mental. Temuan penelitian kualitatif Fadjaryana (2007) terhadap tujuh istri di Kotabaru Kalimantan Selatan menunjukkan bahwa kekerasan fisik, psikis, ekonomi dan seksual yang dialami istri dapat diakhiri dengan jatuhnya talak akibat istri menggugat cerai suami. Dengan demikian, dalam banyak kasus, perceraian menjadi solusi dari beragam penderitaan yang dirasakan istri dalam perkawinan sehingga faktor penghambat perceraian sering menjadi tidak efektif dalam merintangi terjadinya perceraian.

Dukungan terhadap konsep Amato dan Rogers (1997) dapat dibuktikan dari adanya pengaruh tingkat pendidikan terhadap intensi cerai perempuan (Kulik \& Klein, 2010; Orbuch et al., 2002). Pengaruh tingkat pendidikan pada intensi cerai menunjukkan bahwa semakin tinggi tingkat pendidikan istri maka intensi cerainya semakin rendah.

Temuan penelitian ini berlawanan dari hasil penelitian Kposowa (1998) yang menunjukkan bahwa perempuan dengan tingkat pendidikan tertinggi lebih berisiko untuk bercerai dibanding perempuan dengan tingkat pendidikan lebih rendah dan hasil penelitian Fokkema dan Liefbroer (2004) yang menemukan tingginya tingkat pendidikan secara signifikan meningkatkan kecenderungan wanita untuk bercerai.

Di Sulawesi Selatan, status sosial dalam masyarakat merupakan hal penting yang harus dijaga. Dengan tingkat pendidikan tinggi, seseorang diharapkan lebih berhasil dalam menjaga keharmonisan 
keluarga sehingga perempuan/istri yang memiliki tingkat pendidikan tinggi diharapkan mampu menjaga keutuhan keluarganya. Perempuan berpendidikan tinggi tetapi tidak mampu menjaga keutuhan rumah tangganya cenderung kurang dihargai dalam masyarakat. Beberapa partisipan dalam penelitian ini, khususnya yang berpendidikan tinggi membutuhkan proses yang lama dalam memutuskan perceraian karena kurang siap secara mental karena antara lain merasa malu apabila diketahui bercerai dalam masyarakat.

\section{Keterbatasan Penelitian}

Beberapa keterbatasan penelitian adalah sebagai berikut: (1) Nilai reliabilitas faktor hambatan bercerai (nilai Alpha Cronbach 0,6) menunjukkan bahwa konsistensi hasil pengukuran, khususnya pada faktor ini tergolong lemah. Jumlah aitem hambatan bercerai yang sedikit merupakan faktor yang sangat berpengaruh terhadap rendahnya nilai reliabilitas faktor hambatan bercerai. Kondisi partisipan penelitian yang sedang tertekan sehingga tidak memungkinkan untuk diminta menjawab banyak pertanyaan merupakan salah satu faktor yang turut memengaruhi terbatasnya jumlah aitem yang digunakan dalam skala. (2) Gagalnya proses pengumpulan data di PA Jakarta Selatan menunjukkan bahwa masyarakat kelas menengah ke atas lebih tepat apabila didekati secara personal melalui key person yang bisa memberi rasa percaya sehingga dapat berpartisipasi dalam penelitian. Penggabungan metode kualitatif dan kuantitatif dalam penelitian perceraian dapat mereduksi keterbatasan peneliti dalam mengungkap hal-hal penting yang bersifat pribadi dan rahasia sehingga temuan penelitian menjadi lebih komprehensif. (3) Pada awalnya, peneliti ingin meneliti partisipan yang bercerai selain
Islam. Temuan di lapangan menunjukkan bahwa jumlah perceraian dari kalangan selain Islam sangat rendah. Jumlah partisipan yang di peroleh di Pengadilan Negeri hanya tiga orang (beragama Katolik dan Protestan). Data ketiga partisipan tersebut tidak dianalisis agar tidak bias. Fenomena ini menimbulkan pertanyaan, apakah pasangan suami istri non-muslim jarang yang bercerai? Atau apakah ada mekanisme lain yang ditempuh oleh pasangan suami istri non-muslim dalam bercerai? dan (4) Daftar isian sebab perceraian yang ada di Pengadilan Agama saat ini tidak memisahkan sebab perceraian dari pihak istri (cerai gugat) dan suami (cerai talak). Kondisi ini menyulitkan peneliti dalam memilah sebab perceraian dari pihak istri dan suami.

\section{Kesimpulan}

Berdasarkan hasil analisis data maupun pembahasan, dapat ditarik kesimpulan bahwa; (1) intensi cerai dipengaruhi oleh daya tarik negatif (kekerasan dalam rumah tangga, ketidaksetiaan dan tidak bertanggungjawab), hambatan bercerai, dan keyakinan akan hidup lebih baik setelah bercerai. Dinamika psikologis penjelasan model intensi cerai perempuan yang ditemukan adalah: (a) Daya tarik hubungan perkawinan, yang dipengaruhi oleh evaluasi terhadap daya tarik positif (cinta, komunikasi dan pemenuhan materi) dan daya tarik negatif (kekerasan, tidak setia, dan melalaikan tanggung jawab terhadap keluarga) berpengaruh terhadap intensi cerai perempuan. Intensi bercerai perempuan kuat karena daya tarik negatif (hal-hal tidak menyenangkan) sangat dominan dalam hubungan perkawinan; (b) Keyakinan terhadap harapan hidup lebih baik apabila bercerai mencakup harapan bertemu dengan pasangan yang berbeda, atau hidup lebih baik dan 
berkomitmen untuk tidak menikah berpengaruh terhadap intensi cerai perempuan. Perempuan memiliki keyakinan hidup lebih baik setelah bercerai sehingga intensi bercerai yang dirasakan sangat kuat; (c) Hambatan/rintangan yang dihadapi dalam proses bercerai tidak menyurutkan intensi cerai perempuan. Hambatan bercerai yang dirasakan perempuan tergolong lemah sehingga sangat berpengaruh pada kuatnya intensi cerai yang dirasakan. (2) Faktor tidak langsung yang turut berkontribusi pada intensi cerai menurut model yang ditemukan adalah tingkat pendidikan. Tingkat pendidikan yang tinggi memengaruhi intensi cerai perempuan. Perempuan yang berpendidikan tinggi menunjukkan intensi cerai yang rendah.

Dengan demikian, temuan penelitian mengukuhkan model penjelasan intensi cerai berdasarkan teori pertukaran sosial, teori perilaku terencana dan model perceraian Amato dan Rogers (1997) yang diajukan.

\section{Saran}

Berdasarkan hasil penelitian, peneliti menyarankan secara konseptual, sebagai berikut; (1) Pada aspek hambatan bercerai, stigma sosial perlu diteliti pengaruhnya sebagai penghambat perceraian. (2) Faktor religiusitas sebagai faktor tidak langsung yang berkontribusi terhadap perceraian perlu diteliti pengaruhnya. (3) Proses mediasi perlu diteliti secara khusus karena aspek psikologis yang terlibat dalam proses mediasi cukup penting, dan (4) Perlu melakukan penelitian terhadap pasangan suami istri non-Muslim untuk mengetahui bagaimana relasi mereka dalam perkawinan dan bagaimana mekanisme yang ditempuh oleh pasangan suami istri non-muslim dalam bercerai? Secara metodologis. Pendekatan kualitatif untuk meneliti sebab perceraian pada masyarakat menengah ke atas perlu dilakukan. Pendekatan kualitatif dapat memberi keleluasaan untuk melakukan pendekatan personal dalam proses pengumpulan data penelitian. Aitem pada skala dengan reliabilitas kurang dari 0,7 perlu ditambah supaya menghasilkan keajegan jawaban partisipan. Secara praktis, sebagai berikut; (1) Pihak pengadilan perlu memperbaiki daftar isian sebab perceraian yang ada di Pengadilan. Daftar isian yang ada saat ini tidak memisahkan antara sebab perceraian dari pihak istri (cerai gugat) dan suami (cerai talak). (2) Peraturan Mahkamah Agung (PERMA) yang mewajibkan proses mediasi pada perkara perdata dan proses mediasi dalam kasus perceraian yang ditangani oleh hakim merupakan dua hal yang menunjukkan perlunya kehadiran Psikolog secara terstruktur di Pengadilan Indonesia, termasuk di Pengadilan Agama. Sampai saat ini, Hakim yang berperan sebagai mediator dalam mediasi sehingga tujuan yang diharapkan dari proses mediasi terkesan kurang optimal, dan (3) Pihakpihak terkait (Pengadilan agama, Badan Penasehat Perkawinan dan Penyelesaian Perceraian atau BP-4) perlu membuat kebijakan bersama yang bertujuan untuk membekali calon pasangan suami istri, khususnya pasangan Islam dengan keterampilan-keterampilan tertentu yang dibutuhkan dalam mengarungi bahtera perkawinan.

\section{Kepustakaan}

Aghajanian, A., \& Moghadas, A. A. (1998). Correlates and Consequences of Divorce in an Iranian City. Journal Div. Rema, 28, 53-71. http://dx.doi.org/ 10.1300/J087v28n03_03 
Ajzen, I. (1988). Attitude, Personality, and Behavior. Milton Keynes, England: Open Iniversity Press.

Ajzen, I. (2005). Attitudes, Personality and Behavior. New York: Open University Press.

Amato, P. R., \& Marriott, B. H. (2007). A Comparison of High and Low Distress Marriage That End in Divorce. Journal of Marriage and Family, 69(3), 621-638. http://dx.doi.org/10.1111/j.17413737.2007.00396.x

Amato, P. R., \& Previti. D. (2003). People's Reasons for Divorcing: Gender, Social Class, the Life Course, and Adjustment. Journal of Famly Issues, 24(5), 602$626 . \quad$ http://.dx.doi.org/10.1177/ $0192513 \times 03254507$

Amato, P. R., \& Rogers, S. J. (1997). A Longitudinal Study of Marital Problems and Subsequent Divorce. Journal of Marriage and the Family, 59(3), 612624.

American Psychological Association. (2007). Dictionary of Psychology. Washington: American Psychological Association.

Andersen, J. D. (2001). Finacial Problems as Predictors of Divorce: A Social Exchange Perspective. Dissertation. Sacramento: California State University.

Angka Perceraian 2009 Meningkat. (27 Februari, 2010). Diunduh dari: http:// www.esq-news.com/2010/02/27/ angka-perceraian-2009-meningkat/. tanggal 22 Agustus 2010.

Armitage, C. J., \& Conner, M. (2001). Efficacy of the Theory of Planned Behaviour: A meta-analytic review. British Journal of Social Psychology, 40, 471-499.
Asmarany, A. I. (2008). Bias Gender sebagai Prediktor Kekerasan dalam Rumah Tangga. Jurnal Psikologi, 35(1), 1-20.

Bachman, G. F., \& Guerrero, L. K. (2006). Relational quality and communicative responses following hurtful events in dating relationships: An expectancy violations analysis. Journal of Social and Personal Relationships 2006 SAGE Publications.

Bloom, B. L., Niles, R. L., \& Tatcher, A. M. (1985). Source of Marital Dissatisfaction Among Newly Separeted Persons. Journal of Family Issues, 6, 359-373.

Bodenmann, G., Charvoz, L., Bradbury, T. N., Bertoni, A., Iafrate, R., \& Giuliani, C. (2006). Attractors and Barriers to Divorce: A Retrospective Study in Three Europea Countries. Journal of Divorce \& Remarriage, 45(3/4), 1-23.

Bulanda, J. R., \& Borw, S. L. (2006). RaceEthnic Differences in Marital Quality and Divorce. Social Science Research, 123.

Chang, J. (2003). Self-reported reasons for divorce and correlates of psychological well-being among divorced Korean immigrant women. J. Div. Rema, 40, 111-128.

Clarkwest, A. (2007). Spousal Dissimilarity, Race, and Marital Dissolution. Journal of Marriage and Family, 69(3), 639-653.

Cooke, L. P. (2006). "Doing" Gender in Context: Household Bargaining and Risk of Divorce in Germany and the United States. AJS, 112(2), 442-472.

Dong, Q., Wang, Y., \& Ollendick. (2003). Consequences of Divorce on the Adjustment of Children in China. Journal of Clinical Child and Adolescent Psychology, 31(1), $101-110$. 
English, S. M. (1997). A Social Exchange Analysis of Early and Late Divorce. Thesis. Texas Tech University.

Fadjaryana. (2007). Studi Dampak Kekerasan Fisik dan Psikologis terhadap Istri. (Tesis, tidak dipublikasikan). Yogyakarta: Fakultas Psikologi Universitas Gadjah Mada.

Fan, C. S., \& Lui, H. K. (2004). Extramarital Affairs, Marital Satisfaction, And Divorce: Evidence From Hong Kong. Contemporary Economic Policy, 22(4), 442-452.

Fishbein, M., \& Ajzen, I. (1975). Belief, Attitude Intention and Behavior: An Introduction to Theory and Research. Sidney: Addison-Weley Publishing Company.

Fu, X. (2006). Impact of Socioeconomic Status on Inter-Racial Mate Selection and Divorce. The Social Science Journal, 43, 239-258.

Gähler, M. (2006). “To Divorce Is to Die a Bit...": A Longitudinal Study of Marital Disruption and Psychological Distress Among Swedish Women and Men. The Family Joural: Counseling and Therapy for Couples and Families, 14(4), 372-382.

Gahler, M., Hong, Y., \& Bernhardt, E. (2009). Parental Divorce and Union Disruption Among Young Adults in Sweden. Journal of Family Issues, 30(5), 688-713.

Graaf, P. M., \& Kalmijn, M. (2006). Divorce Motives in a Period of Rising Divorce. Evidence From a Dutch Life-History Survei. Journal of Family Issues, 27(4), 483-505.

Hall, J. H., \& Fincham, F. D. (2006). Relationship Dissolution Following Infidenlity: The Roles of Attributions and Forgiveness. Journal of Social and Clinical Psychology, 25(5), 508-522.
Holden, K. C., \& Smock, P. J. (1991). The Economic Cost of Marital Dissolution: Why Do Women Bear a Disproportionate Cost? Annual Review of Sociology, 17, 51-78.

Johnson, D. R., \& Wu, J. (2002). An Empirical Test of Crisis, Social Selecetion, and Role Explanation of the Relationship between Marital Disruption and Psychological Distress: A Pooled Time-series Analysis of Fourwave Panel Data. Journal of Marriage and the Family, 64, 211-224.

Kelly, J. B. (1989). How Adult React to Divorce. In J. M. Henslin (Ed.), Marriage and Family in a Changing Society (pp.427-440). New York: Free Press.

Kitson, G. C., \& Morgan, L. A. (1990). The Multiple Consequence of Divorce: A decade review. Journal of Marriage and the Family, 52, 913-924.

Knoester, C., \& Booth, A. (2000). Barriers to Divorce? When Are They Effective? When Are They Not? Journal of Family Issues, 21(1), 78-99.

Kposowa, A. J. (1998). The Impact of Race On Divorce in the United States. Journal of Comparative Family Studies, 29(3), 529-548.

Kulik, L., \& Klien, D. (2010). Swimming Against the Tide: Characteristics of Muslim-Arab Women in Israel Who Initiated Divorce. Journal of Community Psychology, 38(7), 918-931.

Lorenz, F. O., Simons, R. L., Conger, R. D., Elder, G. H., Jr., Johnson, C., \& Cao, W. (1997). Married and Recently Divorce Mothers' Stressfull Events and Distress: Tracing change across time. Journal of Marriage and the Family, 59, 219-232.

Maryati. (2007). Faktor Penyebab Cerai Gugat. Studi Kasus di Pengadilan 
Agama Kota Jambi. Majalah Hukum Forum Akademika, 16(2), 95-109.

Nadia, I. F. (1998). Kekerasan terhadap Perempuan: Kekerasan Terhadap Perempuan dari Perspektif Gender. Jakarta: Yayasan Lembaga Konsumen Indonesia - The Ford Foundation.

Nock, S. L. (2001). The Marriage of Equally Dependen Spouses. Journal of Family Issues, 22(6), 756-777.

Orbuch, T. L., Veroff, J., Hassan, H., \& Horrocks, J. (2002). Who will divorce: A 14-year longitudinal study of black and white couples. Journal of Social and Personal Relationships, 19(2), 179-202.

Rasche, H. J. (1987). Divorce, In M.B. Sussman \& S.K. Steinmetz, (Eds). Handbook of Marriage and the Family, (pp. 597-624). New York: Plenum.

Reis, H. T., Collins, W. A., \& Berscheid, E. (2000). The Relationship Context of Human Behavior and Development. Psychological Bulletin, 126(6), 844-872.

Rogge, R. D., \& Bradbury, T. N. (1999). Till Violence Does Us Part: The Differing Roles of Communication and Aggression in Predicting Adverse Marital Outcomes. Journal of Consulting and Clinical Psychology, 67(3), 340-351.

Salinah. (2004). Pengalaman Perempuan Yang Mengajukan Cerai Gugat. (Studi Kasus Cerai Gugat di Propinsi Kalimantan Selatan). (Tesis., tidak dipublikasikan). Jakarta: Program Studi Kajian Wanita PPS Universitas Indonesia.

Shortt, J. W., Capaldi, D. M., Kim, H. K., \& Owen, L. D. (2006). Relationship Separation for Young, At-Risk Couples: Prediction From Dyadic Aggression. Journal of Family Psychology, 20(4), 624631.

Simon, R. L. Johnson, C., \& Lorensz, F. O. (1996). Family Structure Differences in Stress and Behavioral Predisposi- sitions. In R.L. Simons \& Associates (eds), Understanding Differences between Divorce and Intact Families, Stress and Interaction, and Child Outcome (pp 4564). Thousand Oaks, CA: Sage.

Stanley, S. M., Markman, H. J., \& Whitton, S. W. (2002). Communication, Conflict, and Commitment: insights on the Foundation of Relationship Success from a National Survei. Family Process, 41(4), 659-675). http://dx.doi.org/ 10.1111/j.1545-5300.2002.00659.x

Sweeney, M. M. (2002). Remarriage and the Nature of Divorce Does It Matter Which Spouse Chose to Leave?. Journal of Family Issues, 23(3), 410-440.

Wagner, M., \& Weiss, B. (2002). A MetaAnalysis of German Research on Divorce Risk. Cologne: Research Institute for Sociology University of Cologne.

Wagner, M., \& Weiss, B. (2004). On the Variation of Divorce Risks in Europe: A Meta-Analysis. Paper Prepared for "The $3^{\text {rd }}$ Conference of the European Research Network an Divorce". Germany: University of Cologne.

White, L. K. (1990). Determinants of Divorce: A Review of Research in the Eighties. Journal of Marriage and the Family, 54(4), 904-912.

Wolcott, I., \& Hughes, J. (1999). Towards Understanding the Reasons for Divorce. Working Paper, 20. Australian Institue of Family Studies.

Zakiyah, Y. T. (2005). Latar Belakang dan Dampak Perceraian (Studi Kasus di Pengadilan Agama Wonosobo). (Skripsi tidak dipublikasikan). Semarang: Fakultas Ilmu Sosial, Universitas Negeri Semarang.

Zargar, F., \& Doost, H. T. N. (2008). Divorce Incidence Factor in Falavarjan. Journal Family Research, 3, 737-749. 